\title{
DAMOLLA SABIT B. ABDÜLBAKI: TEMEL KELAMI DÜŞÜNCELERi
}

\author{
Yrd. Doç. Dr. Mehmet RUZiBAKi
}

Sabahattin Zaim Üniversitesi İslami Ilimler Fakültesi

\begin{abstract}
Change and reform is an essential part of humanity. Whereas it is impossible to imagine the absence of change and reform throughout the history of mankind, such changes follow certain patterns and principles. Unfortunately, these do not always proceed in the positive sense. However, the process can be decomposed into variable and constant parts, whose distinction could make the ongoing changes more useful. To achieve this, the concepts of change and reform are studied in the first part of our work. We elaborate on the guidelines necessary for distinguishing the variable and constant parts within the change process. Secondly we investigate movement's leaders Damolla Sabit b. Abdulbaki's position in the movement.
\end{abstract}

Keywords: Quran, Islam, religion, changing and unchanging constants, change, renewal, theology/kalam, rehabilitation, reform.

\section{Giriş}

Sabit b. Abdulbaki, Tam adı, Hacı Damolla Sabit b. Abdulbaki Kemal-i esSelefi el- Kaşgari'dir. 1300/1883 yılında Kaşgar'a komşu olan Artuş’un Azak kasabasında doğmuştur. Zekâsı ve kabiliyeti sayesinde kendi kendini yetiştiren, ondan sonra Buhara'ya giderek daha mükemmel bir medreseyi bitiren Abdülbaki, birkaç yıl Kaşgar'da bulunan Hanlık Medresesinde müderrislik daha sonra İli vilâyetinde ise bir müddet kadılık yapmıştır. Gulca cemaatinin teklifiyle 1929'da Gulca'ya gidip birkaç yılda orda kalmış usta bir vaiz ve âlim bir insandı. Seleflerin Kuran ve sünnet çizgisinde olduğunu Haleflerin ise bazı tevillere gittiklerini fakat tevil yapma konusunda haklı olmalarına rağmen kitap ve sünnet çizgisinden uzaklaştıklarını savunur. Kelamcıların gereksiz tartışmalara dalarak asıl konuyu ihmal ettiklerini ileri sürmüştür. Akaid Cevheri eserinin giriş bölümünde bu konu üzerinde uzunca durmuştur. Çağdaş ulemanın da bilgisine göre amel etmediklerini, talebelere samimi bir şekilde eğitim vermediklerini dile getirir. Mantıktan İsaguci Arapça dilbilgisinden Şerhi Molla adlı kitaplarla talebelerin tahsil hayatını boşa geçirdiklerini savunmuştur. Hatta kendisi talebe iken, talebeler arasında bir birleriyle mektuplaşırken "şerhi molla zındanına giriptar olmağaysız (Allah sizi şerhi molla hapsanesi ile imtihan etmesin)" diye yazarak mevcut eğitimi yermiş ve eğitimin yenilenmesi gerektiğini öne sürmüştür.

Hicri 1345 ’te Rusya, Mısır, Mekke, Medine, Hindistan ve Türkiye’yi ziyaret 
ederek, oralarda birçok inceleme ve tetkiklerde bulunmuştur. El-kasidetu's-Seniyye fi'l-Akideti's-Sünniye adlı eserinin giriş bölümünde bu seyahatinden bahsederken şöyle demektedir:

“Türkiye'nin yeni rejimi dini âlimlere değer vermediğinden fikri teatide bulunabileceğim fazla kimse bulamadım. Ama Misır öyle değildi."

İstanbul'dan Mısır'a geçen Sabit Damolla Mısır'da bir müddet kaldıktan sonra Hicaz'a geçer oradan da hac farizasını eda etmek için Mekke'ye gitmiştir. Mekke'den Taife olan yolculuğu esnasında El-kasidetu's-Seniyye fi'l-Akideti's-Sünniye adlı eserini telif etmiştir. Ayrıca hac merasiminde Abdurraşid İbrahim başta olmak üzere birçok fikir adamlarıyla görüşmüştür. Daha sonra Hindistan'a gitmiş ve orada telif ettiği kitabını neşretme imkânını elde etmiş̧ir.

1917 yılı Rusya Bolşeviklerinin Orta Asya'ya hâkim olmaları Çin komünistlerinin de güçlenmesine yol açtı. Böylece bölgeyi sömürgesi altına almak isteyen ikinci bir güç zuhur etti. Sömürgeye karşı direnişin sistematik bir şekilde yürütülebilmesi için yeni bir hükümetin kurulması lazımdı. Bu işin gerekliliğini hisseden ilk Sabit Damolla oldu. Bu zat Hoten'deki ayaklanma başlamadan birkaç ay önce yurt dışından dönmüştü. Sovyetler Birliği, Türkiye, Mısır, Suudi Arabistan, Hindistan gibi devletlere yaptığı ziyaretler esnasında bazı incelemelerde bulunan Sabit Damolla; Hoten'deki Guomindang (Milliyetçi Çin) hükümetine karşı ayaklanmanın patlak vermesinden evvel, genel durumla ilgili Muhammed Emin Buğra'ya verdiği bilgide; dünya üzerindeki hiçbir devletin Doğu Türkistan mücadelesine yardım edemeyeceğini, bu sebeple özellikle ayaklanmalar patlak verdikten sonra komşu devletlerin desteğini kazanmanın lüzumunu vurgulamıştır. ${ }^{1} 1930$ 'da Muhammed Emin Buğra Gulca'ya geldiğinde Sabit Damolla ile bağımsılılı mücadelesi için istişareler yaptılar. Ayaklanmayı Hoten'de başlatmayı uygun gördükten sonra Damolla yurt dışına, M. Emin Buğra'da Hoten'e yola çıtıtı.

Sabit Damolla bağımsızlık hareketine yetişebilmek için Hindistan üzerinden Hoten'e geçti. Sabit Damolla, Muhammed Emin Buğra ile istişare ettikten sonra Yarkent'teki Hoten askerlerinden 2000 kişiyi komutası altına alıp Kaşgar'a gelir. Kaşgar'da kumandan Tümür ile yardımlaşarak yeni şehir kalesine sığınan Tunganları (Çinli Müslüman) bertaraf edip millî mücadeleyi başlatmak için yola çıkar. Fakat Kaşgar'daki ayaklanmada, ikiyüzlü, hain olduğu sonradan anlaşılan bazı münafiklar mücahitlerin arasına sızmıştı. İşte bunlar kumandan Tümür'ün aklına bölücü fikirler yerleştirirler. Yani, Sabit Damolla'ın cemaat içinde büyük itibarının olduğunu ve Kaşgarlı olması sebebiyle hâkimiyeti Tümür'den alıp ele geçirebileceği ihtimaline inandırdılar. Sabit Damolla'ya karşı komutan Tümür’ün nefretini uyandırdılar, Tü-

1 http://www.hurgokbayrak.com/yeni_sayfa_177.htm. Erişim tarihi 11. 06.2014. 
mür'e Kolordu Komutanı unvanını veren Çinliler ile Müslümanların arası bozulur. Düşman henüz yok edilmemişti. Bir gece, 02.08.1933 tarihinde komutan Tümür hiç beklenmedik bir anda Sabit Damolla, Muhammet Emin Buğra'nın kardeşi olan askeri kumandan Emir Abdullah (Şah Mensur)'1 yakalatıp hapse attırır. Hoten'den gelen 2000 askerin de silahlarına el konur. 28.9.1933 tarihinde komutan Tümür bir gezintiden dönüşü sırasında Kaşgar'da Tunganlar tarafindan şehit edilir. Sabit Damolla hapisten çıkıp derhâl hükümet kurma çalışmalarına başlar. 12.11.1933 tarihinde Kaşgar'da Doğu Türkistan İslam Cumhuriyeti'nin kurulduğu ilan edilir. Devlet kurma bildirisi Hindistan radyosundan bütün dünyaya duyurulur. Ay yıldızlı gök renkli bayrak Kaşgar semalarında dalgalanır.

Doğu Türkistan pasaportu ile Hindistan'a giden Doğu Türkistan hükümeti Dış İşleri Bakanı Kasım Can oradaki İngiliz hükümetinin bağımsız Doğu Türkistan devletini tanımasını istemişti. İngiliz hükümeti: "Meselenizi Nencin hükümetiyle görüşüp halledin! Biz sizi değil Nencin hükümetini tanıyoruz" şeklinde cevap vermişti. Anlaşılıyor ki İngiliz hükümeti egemenliği altından çıkma tehlikesi doğabileceğini düşündüğü için Hindistan'ın yanında müstakil bir devletin kurulmasından rahatsızd. 11.4.1934 tarihinde Hoca Niyaz Hacim'in emriyle Mahmut Muhiti, Sabit Damallom'ı tutuklayarak huzuruna getirdi. Damolla'yı Ruslara teslim etmek için Aksu'ya gönderen Hoca Niyaz bu teslim etme karşıllı̆ında Rusların vereceği, silahları almak maksadıyla Örkeş Tam (Rus Sınırı)'a gitti. Ruslar Aksu'da Sabit Damolla’yı alıp Urümçi'ye götürerek Şing Şi Sey’e teslim etti. Örkeş Tam'da Rusların vaadinin yalan olduğu anlaşıldı. Ruslardan bir tek tüfek dahi alamadan Hoca Niyaz tekrar Rusların görevlendirilmesi ile Aksu'ya geldi. Daha sonra Vali muavini olabilmek için Urümçi’ye gitti. Sabit Damolla 1934 tarihinde Çin Generali Şinğ Şi Sey tarafindan idam edildi. ${ }^{2}$

\section{Damolla'nın Eserleri}

Sabit Damollo'nın telif ettiği eserlerine bakıldığında bunların çoğunlukla kelam üzerine verilmiş olduğu görülmektedir. Bunlar tercüme ve telif eserler olarak ikili bir tasnife tabi tutmak mümkündür: şu şekildedir:

Tercüme ve Şerh eserleri:

- Beyanu's-Sünne. Tahavî’nin bu eserini Uygur Türkçesine tercüme etmiştir.

2 http://www.hurgokbayrak.com/yeni_sayfa_177.htm. Erişim tarihi 11. 06.2014; onun devlet adamlığı hakkında ayrıca bkz. Nur Ahmet Kurban, "Davet Adamlığından Devlet Adamlığına Sabit Damolla” Turkish Stu-dies - International Periodical For The Languages, Literature and History of Turkish or Turkic, Volume 9/1 Winter 2014, Ankara. 
Yazar eserde Tahavi'nin inanç sistemini aktarmakla yetinmeyip bunlara ilişkin kendi düşünce sistemini de detaylı olarak vermeye azami gayret göstermektedir. Bundan dolayıdır ki bu eser, yazarın kelami düşünce sistemine ilişkin "Akaid Cevheri'nden sonra yararlandığımız kaynaklar arasında yer almaktadır. Üçüncü sırada ise el-Kasidetü's-Seniyye fi'l-Akâidi's-Sünniyye gelmektedir. Eser Hindistan'da 1932 yılında basılmıştır.

-Şerhu Elfiye. İbn Malik'in Elfiye adlı eserine Arapça bir şerh yazmıştır.

- Şirin Kelam. San‘âtullah Dikpoltan’ın bu eserini Uygur Türkçesine tercüme etmiştir.

\section{Telif eserler:}

- İslam Kanunu. O, bu eseri Uygur Türkçesiyle yazmıştır. Ancak bu eser basılamamıştır. Hac dönüşü yazmayı planlamış ancak yetiştiremeyeceğini anlayınca yerine genç nesil için özet bir akide esasları risalesi yazmayı düşünmüştür.

-el-Kasidetü's-Seniyye fi'l-Akâidi's-Sünniyye. 12 sayfadan oluşan risaleyi Bunu Arapça olarak yazmış ve Arapça olarak şerh etmiştir. 1932 yılında Mekke'den dönerken Hindistan'da bastırmıştır. Eserde daha ziyade Ehl-i sünnet'in özellikle selefi düşüncesinin inanç ilkelerini şiirsel bir tarzda ortaya konulmaktadır. Ehl-i sünnet'in diğer mezheplerden ayrılan yönleri risalede tespit edilmeye çalışılmaktadır. Eser, İbn Malik'in meşhur Elfiye adlı eserinden ilham alınarak yazıldığı tespit edilmektedir. Yazar da bunu dile getirmekten çekinmemektedir: "Sonrasında Hindistan beldelerini, ulemasını ziyarete muvaffak oldum. Allah bana İbn Malik'in "Elfiye" adlı eserini basma imkânını verdi. Çünkü insanlar duygu ve anlayış bakımından farklıdırlar. İstedim ki Kaside'nin nazmı, İbn Malik'in söz konusu eseriyle birlikte, inci ile bir diğer incinin birlikte dizilmesi gibi olsun. Yoksa arpa daneleriyle altın birlikte bir kolyeye dizilmezler. İkisini bir arada ele almamın sebebi, daha çok fayda sağlasın ve bununla da bir genellik kazansın istedim."

-Akâid-i Cevheriyye. Bu eser Uygur Türkçesiyle yazılmıştır. Henüz daha Türkiye Türkçesine aktarılmayan risale 24 sayfadan oluşmakta olup gençlerin kısa ve öz olarak saf ve sağlam İslam inanç sistemini öğrenmeleri amaçlanmıştır. İslam Kanunu adlı eseri yazamayacağını düşünen Sabit b. Abdülbaki bu kısa risaleyi kaleme almaya karar vermiş ve onu dostlarına hurma ve zemzem yerine hediye etmek istemiştir. 1932 yılında Hindistan'da basılmıştır. Kelam, daha doğrusu akaid inancıyla alakalı yazarın düşüncelerinin temelini oluşturan eser, bizim açımızdan müellifin kelam ve kelama ilişkin düşüncelerini öğrenemmizde en kapsamlı yazı niteliğini taşımaktadır.

- Rûşen Beyân Türkî Tefsir-i Kur'ân. Bunu Uygur Türkçesiyle yazmıştır. Tam tefsir olduğu bilinse de son cüzü dışındaki bölümleri matbu değildir. 


\section{Damolla'nın Temel Kelami Düșünceleri}

\section{Allah Teâlâ'nın Sıfatları}

Orta Asya ve İdil-Ural bölgelerinde çoğunlukla Ehli Sünnet kelam anlayışı hâkimdir. Fakat Mutezile kelam anlayışına karşıt bir anlayış olarak gelişen ehlisünnet görüşü özellikle de Eşâri kelam görüşü olarak benimsenen görüşler uygulamada tam bir Cebriyye görüşü olarak toplum hayatına yansımıştır. Buna bağlı olarak insanlar özgür irade ve sorumluluk taşıma duygusundan tecrit edilmiştir.

Emeviler döneminden itibaren İslam toplumunda Kuran ve sünnete aykırı olarak oluşturulan kader anlayışı neticesinde Müslümanlar yaptıkları şeyler ve başlarına gelen musibetlerden (hâşâ) Allah'ı sorumlu tutar hâle gelmişlerdir. İşte bu sebepten bölgede parlayan yeni yıldızlar Müslüman toplumunun derin uykusundan uyanması ve yanlış düşüncelerden kurtulmaları için köklü bir hareket başlatmışlardır. Mevcut düşünce sisteminin değiştirilmesi ve yerine dinin asıl kaynağından beslenen doğru düşüncenin gelmesi gerçekleşmesi beklenen asıl hedef idi.

$\mathrm{Bu}$ hedefe ulaşmayı amaçlayan âlimlerden biri olan Sabit b. Abdulbaki'ye göre, halef akidesi mücmelleri açıklayan daha derin bilgi, Selef akidesi ise meselenin detayına girmeksizin Allah'a havale etmeleriydi. Bu yöntemin dini düşünce aç1sından daha sağlıklı olduğu görülmektedir. Buna göre, müteahhirin bilgisi daha do $\breve{g}-$ ru ve düşüncesi de daha geçerli, Seleflerin ise daha ihtiyatlı ve bilgisi olmayan şeyler üzerinde durmaktan oldukça kaçındıkları bilinmektedir. Özet olarak halefler, seleflere göre daha bilgilidir. Zira müteahhirin döneminde imkânlar daha geniş ve eğitim müfredatları daha güzel bir şekilde düzenlenmiştir. Ancak konuya daha derinden bakınca gerçeğin böyle olmadığını şöyle ifade eder:

Selef akidesi sağlam bir şekilde Kuran ölçüsü ve sünnet kurallarına göre tesis olunmuş, hiçbir şekilde şek, şüphe ve batıl karışmamıştır. Dolayısıyla Müslüman olan herkes tarafından kabul edilmesi ve sıkı bir şekilde sarılması gerekir. ${ }^{3}$

Sabit b. Abdulbaki “El-Kasidetu's-Seniyye fi'l-akidetu's-Sünniyye” adlı eserinde, selef akidesini tercih eden haleflerinin hata etmediğini aksine isabetli bir tutum içinde olduklarını söylemiştir. Uygur Türkçesi olarak kaleme aldığı "Akaid Cevheri" adlı eserinde, "Selef akidesine; ilmi kelam ve ilmi tasavvuf vasitasiyla, Yunanlıların kuşku ve kuruntuları, İranlıların hurafeleri, Asurlular ve Kildanilerin asılsız hikâyelerinden, Finikelilerin hayallerinden, Rafızıların cehaletinden biraz karıştığını bildirmektedir."

3 Sabit b. Abdülbaki, el-Kasidetu's-Seniyye fi'l-akidetu's-Sünniyye, Delhi, Şahicihan, mahbubi'l-matabi, 1932, s. 1 
$\mathrm{Bu}$ sebepten, Haleflerin tevhidi, Seleflerinki gibi saf ve halis kalmamış, Kuran ve sünnetten uzaklaşarak Allah'tan istenecek şeyleri mahlûktan istemişler, Allah'a has bazı sıfatların mahlûklarda da olabileceği yanlış inancına düşmüşlerdir. İtikadi meseleleri ispat etmede Kuran ve Sünnetin yetersiz olduğunu ileri sürerek kelam ilmini esas almışlardır. Hatta kelam ilmini Kuran ve Sünnetin önüne koymuşlardır. Nitekim kelami ifadeler, taşa işlenen bir nakış ya da küçüklüğümüzden beri tekrarlayarak kanımıza yerleşen Kuran süreleri gibi olmuştur. Evham ve hayaller çoğalmış, düşman safında desiseler artmış, her firka kendi fikir ve hevalarına tabi olup kendi mesleklerini yükseltmek ve başkalarının mesleklerini red etmeye başlamışlar.

$\mathrm{Bu}$ nedenle mevcut kelami düşünceleri eleştirel biçimde ele alan Sabit b. Abdulbaki’ye göre, Seleflerin tevhitleri son derece halis, imanlarının pak sünnet-i seniye çizgisinde, doğru yol üzerinde, bidat ve günahtan uzaktır. Ahlak, amel ve davranışlarının ölçüsü, idare, hükümet ve siyasetlerinin kanunu, Kuran ve sünnet olduğundan ahlak, insaniyet, sadâkat, nezaket, vefa, safa, sıla-i rahim, şefkat, özgürlük incelik gibi erdemliklerde üstün mertebede olduğu görüşündedir. Ayrıca onlar oburluk, şeytanlık, kurnazlık suistimal ve bağnazlık gibi kötü ahlaklardan külliyen uzaktırlar. Onlar Allah Teâlâ'nın şu ayetinde müjdelenenleri çağrıştırır: “Tağut'a kulluk etmekten kaçınan ve Allah'a içten yönelenler ise; onlar için bir müjde vardır, öyleyse o kullarıma müjde ver. Ki onlar, sözü dinlerler ve en güzeline uyarlar. Işste onlar, Allah'ın kendilerini hidayette kabul ettikleridir ve onlar, sabit akll sahipleridir. ${ }^{4}$

Sabit b. Abdulbaki selef ve halefle ilgili görüşlerinde Muhammed Reşid R1zadan etkilenmiştir. Nitekim o, İstanbul, İskenderiye, Kahire, Hicaz ve Hint ulemalarıyla fikir teatisinde bulunmuş, özellikle Muhammed Reşid Rıza ile birçok ilmi mecliste birlikte olduğunu ve onun "halefler içinde kitap ve sünnete muvafik Allah'ın nusretine layık kişilerin çok az olduğunu” söylediğini nakletmektedir. Ayrıca Muhammed Reşid Rıza'dan büyük mürşid diye bahseder. ${ }^{5}$ Görülüyorki Sabit b. Abdulbaki yenilenme hareketleri konusunda Muhammed Reşid Rıza’yı kendine örnek almiştır.

Fakat Sabit b. Abdulbaki selef ve halef karşılaştırmasını yaparken diğer yenilikçiler gibi Allah'ın zatı ve sıfatlarıyla ilgili kelami tartışmaların detaylarına yer vermez. Sadece kulların özgür irade sahibi muhtar varlıklar olduğunu ve buna göre hesaba çekileceğini vurgular. ${ }^{6}$ İyilik ve kötülükleri takdir eden Allah, meydana geti-

4 Zümer Suresi, 39 / 17-18; Sabit b. Abdulbaki, Akaid Cevheri, Delhi, Şahicihan, mahbubi'l matabi. 1932, s. 4.

5 Sabit b. Abdulbaki, Akaid ..., s. 5.

6 Sabit b. Abdulbaki, Akaid..., s. 2. 
ren ise kuldur. ${ }^{7}$ Nitekim Allah Teâlâ şöyle buyuruyor: "Sonra da ona iyilik ve kötülük kabiliyeti verene andolsun". ${ }^{8}$

Sabit b. Abdulbaki, haleflerin Allah'ın sıfatlarıyla ilgili ayet ve hadisleri tevil ederken sağlam gerekçelere dayandıklarını ve amaçlarının da doğru olduğunu dolayısıyla da tevil konusunda haleflerin haklı olduğunu dile getirmektedir...

Ayrıca Sabit b. Abdulbaki Peygamber'in (s.a.v) İslam ümmetinin 73 firkaya bölüneceği hadisinin haleflerde gerçekleştiğini ileri sürmektedir. Zira halefler itikadi konularda çeşitli firkalara bölündüğü gibi furu ve ahkâmla ilgili konularda da farklı fikirler serdetmişlerdir. ${ }^{9}$ Bundan dolayıdır ki tam bir teslimiyetçi selefi inanca sahip olmakla övünen Damolla tevhit ilkesiyle bağıntılı olarak vacip olan şeylerin neler olduğuna dair soruya Allah'ın sıfatlarını bilmenin kula vacip olduğunu bildirmektedir. Bunlar ona göre şu şekilde sıralanabilir: Allah Teâlâ'nın varlığının ne başlangıcı vardır ne de sonu. Allah Teâlâ hiçbir şeye benzemez. Hiçbir şey de ona benzemez. Mekâna muhtaç değildir. Zamanla değişime uğramaz. Zatında, sıfatında ve fiilinde tektir, benzeri yoktur. Kendi nefsi ile kaimdir. Gani, kadir, mürit ve dilediğini yapandır. Yaptığı şeylerden sorgulanamaz. Vacip ve mümkün bütün âlemleri ve her şeyi yoktan var eden O'dur. Müminleri bilir, her şeyi görür, işitir. Bir şeyi yapması aynı anda ikinci bir şeyi yapmasına engel değildir. Hüküm ve kararlarında adildir. Yaratış, icat ve emirlerinde, takdir ve tedbirlerinde münferittir. Kimse ortak değildir. Bir şeyi var etmek istediğinde ona "ol" der o şey belirlenen süreçte var olur. Allah Teâlâ kemal sıfatlarla 'müttasiftir' diye içtenlikle inanmaktır. ${ }^{10}$

Damolla daha sonra Allah'ın kemal sıfatlarının "hayat, kader, irade, ilim, sem'i, basar, kelam, tekvin, vücut, kıdem, beka, kendi nefsi ile kaim olmak, tek ve yegâne olmak, diri olmak, kadir olmak, mürit olmak, semi' olmak, basir olmak ve mütekellim olmak" şeklinde olduğunu söylemektedir. Muhalefetün li'l-havadisi ise bir sonraki cümlesinde bunlara ilave etmekte buna delil olarak ta "Hiçbir şey onun benzeri değildir" mealindeki ayetini göstermektedir. Burada dikkat edildiğinde selbi ve subuti sıfatlar birlikte ve ayırt edilmeyerek verilmiştir. Ayrıca Matüridi ekolüne mensup olması hasebiyle de tekvin'i Eş'ariler'in aksine Allah'ın sıfatlarından birisi olarak görmektedir.

\section{Akıl-Vahiy Uzlaşmast Sorunu}

Akı1, idrak, muhakeme kabiliyeti, düşünme, kavrama ve bilgi elde etme gücüdür. Bir insanın ilahî emirlerden sorumlu olup olmaması onun bu güce sahip olup

7 Sabit b. Abdulbaki, Akaid..., s. 16.

8 Şems, $91 / 8$.

9 Sabit b. Abdulbaki, Akaid...i, s. 5.

10 Sabit b. Abdülbaki, Akaid..., s. 12. 
olmamasına bağlıdır. Yani akıl, teklifin temel şartıdır. En önemli görevi de vahyi anlamak ve hayata geçirmektir. Sözlükte gizli konuşma, işaret etme, emretme, ilham etme, ima etme, acele etme, seslenme ve fisıldama manalarına gelen vahiy kelimesi terim olarak yüce Allah'ın Cebrail vasitasıyla emirlerini peygamberlerine bildirmesi anlamındadır.

Vahyin yukarıda zikrettiğimiz sözlük anlamı bilindiği üzere genel bir manadır. Hiçbir şekilde ilahîlik özellik taşıması şart değildir. Allah Teâlâ ile elçileri arasında olduğu gibi insanlar ve cinler arasında da olabilir. Mekke müşrikleri vahye bu pencereden bakmış ve kendilerine vahiy okunduğu zaman şöyle demişlerdir: " $T a$ mam! İsittik... İstersek, biz de bunun bir benzerini söyleyebiliriz. Bu, eskilerin yazıp kaldırdıklarından başka bir şey değildir."

Terim manası ise vahyin yüce Allah tarafindan insanlar arasından seçilen elçilerine Cebrail vasıtasıyla indirilmesi olarak anlaşıla gelmiştir. Vahye bu pencereden bakıldığında, vahyin mahiyetleri anlaşılmaktadır ki, bu hususta kesin ve objektif bir bilgi edinmeye yönelik bir gayretin herkesi tatmin edebilecek sonuçlar vermesi mümkün değildir. Allah Teâlâ bu anlamdaki vahyin çeşitleri ${ }^{12}$ nden bahsetmekle beraber mahiyetlerini tam olarak bildirmemiş, bundan sorumlu da tutmamıştır. Çünkü bu mükelleflerin esas ilgi noktası değildir. Ancak mükelleflerin ileride açıklayacağımız üzere en çok üzerinde durdukları vahyin bu yönü olmuştur. Vahyin mükellefleri ilgilendiren esas tanımı şöyle olmalı: Vahiy, insanoğlunun dünya ve ahiret saadetinin temini için Cebrail aracılığıyla peygamberlere indirilen ilahî öğretinin bir bütünüdür. Yani ilahî ilkeler bileşimidir. Bunlar son peygamber Muhammed'e (s.a.v) Kur'an adıyla indirilmiştir. Ancak ne eskiden ne de çağımızda vahyin bu yönüne yetirince önem verilmiştir. Ama akıl, düşünme, kavrama ve bilgi elde etme gücü. İnsanın düşünme, bilme, davranışlarını belirleme, denetleme, yargılaması ya da iyiyi kötüden, doğruyu yanlıştan, hakkı batıldan ayırmasıyla ilgili kabiliyeti veya dirayetinin topluca adıdır. Belli yargıların başka yargılar ile mantıksal bağlantılarını kavramak; olayları yönlendiren ve düzenleyen ilkeleri bulmak, dolayısıyla geleceğe ilişkin ya da gelecekte olacak olaylar konusunda öngörüde bulunmak kabiliyeti şeklinde de tanımlanabilir.

Batı'da cereyan eden bu çekişmeler 19. asrın son çeyreği ile 20. asırın başlarında Orta Asya ve İdil-Ural bölgesinde faaliyet gösteren yenilikçiler tarafindan akılvahiy ilişkisi ve bunun bir başka yansıması olarak ilim ve dini uzlaştırmanın mümkün olup olmadığı şeklinde gündeme getirilmiştir. Bunun iki önemli sebebi vardır: Bunlardan birincisi; toplumun bir kısım ulemanın, Batı'da gelişen tabii bilimlerle din nassında bir zıtlık görmesi, tabii bilimlerin dini dışladığını düşünmesidir. Top-

11 Enfal, 8 / 31.

12 Bkz. Al-i İmran, 3 / 79. 
lumdaki bu yanlış ilim anlayışı neticesinde dinî ilimler esas kabul edilmekte, söz konusu tabii bilimlerin mektep ve medreselerde okutulması zorlaşmakta, bu nedenle sürekli karanlığa koşan bir toplum oluşmakta idi. Durumun bu şekilde tezahür etmesi de yenilikçilerin meseleyi sık sık gündeme getirerek tartışılmasına vesile olmaktadır. İkincisi ise; dinî ilimlerde dahi aklın devre dışı bırakılıp taklidin esas tutulmasidir.

Abdünnasìr Kursavi bu hususta yenilikçilere öncülük eden isim olmuştur. F1kıh ve kelam konusundaki fikirleriyle aklın önemini vurgulamış ve kör taklidin reddedilmesi gerektiğini ${ }^{13}$ savunmuştur. Kursavi’nin bu konudaki görüşleri kendisinden sonra gelen yenilikçilere bir 1şık vazifesi görmüştür. Nitekim ondan hemen sonra gelen yenilikçilerden Şehâbeddin Mercânî (1818-1889) ${ }^{14}$, akıl ile vahyin (hikmet ile şeriatin) ikiz kardeş oldukları ve her ikisi de aynı kaynaktan beslendiği için, doğruya ulaşmada eşit durumda bulundukları görüşünü savunmaktadır. ${ }^{15}$

Akıl-vahiy konusu 19. Asır yenilikçileri tarafından din ve ilim şeklinde dillendirilmiştir. Akıl-vahiy ilişkisi konusunda zikredilen fikirlerin temelde Kuran kaynaklı olduğu tespit edilmektedir. Bu görüşler bazı büyük âlimlerin ve filozofların savunduğu temel hususlardır. Mesela Gazali İhyau Ulûmi'd-Din, Meâricü'l-Kuds ve Kânunu't-Tevil adlı eserlerinde, akıl ile vahyi, din ile ilmi birleştirmenin mümkün olduğunu, aklın ve naklin birer asıl olarak alınıp her ikisine de layık olduğu değerin verilmesi gerektiğini savunmaktadır. ${ }^{16} \mathrm{Bu}$ ise hemen hemen Mercânî'nin görüşlerinin aynısıdır. Gazali dışında; Kindî, Farabî, İbn Rüşd gibi filozoflar da din ile ilmi uzlaştırmaya çalışmışlardır. ${ }^{17}$ Carullah da din ile ilmin, akıl ile naklin birbiriyle uyuştuğunu, uzlaşmaz gibi görünen durumların her iki tarafın taassuplarından kaynaklandığını ve zamanla, keşifler arttıkça, bu taassup ve gururun ortadan kalkmasıy la din ile ilmin uzlaşmaz gibi görünen yanlarının ortadan kalkacağını, insanların

13 Bu konuyla ilgili bkz. İbrahim Maraş, Türk Dünyasında Dini Yenileşme, Ötüken yay. İ tanbul 2002, s. 117-125.

14 Mercani'nin hayatı ve görüşleri için bkz. İbrahim Maraş, Türk Dünyası..., s. 73-79.

15 Şehâbeddin Mercânî, Kitâbu Nâzûrati'l Hakk fi Farziyyeti'l 'İ̧̧âi ve in Yegibi'ş̧ Şafak, Hazane mat., Kazan 1287/1870, s. 119.

16 Mehmet Bayrakdar, İslâm Felsefesine Giriş, Ankara 1997, s. 213-218; Ruhattin Yazoğlu, Gazâlî Düşüncesinde Ruh ve Ölüm, Atatürk Üniversitesi Sosyal bilimler Enstitüsü Bas1 mamış Doktora Tezi, Erzurum 1998, s. 62-65; İbrahim Agâh Çubukçu, Gazalî ve Şüpheci lik, Ankara 1989, s. 71-72.

17 Bkz. Mehmed. Bayrakdar, İslâm Felsefesine Giriş, Ankara 1997s. 150-158; İbn Rüşd, Faslu'l-Makal, çev. Süleyman Uludă̆, İst. 1985, s. 163-164. 
dine daha çok sarılacağını ifade etmektedir. Aynı husus Ziyâeddin Kemâli tarafından da savunulmaktadır. ${ }^{18}$

Sabit b. Abdulbaki Damolla ise kaleme aldığı "Fi zikri'l-Akli ve Medhihi" ad11 şiiri ile aklın önemini ortaya koymakla yetinmiştir. Ona göre akıl, eşyanın hakikatini bilmeyi sağlayan bir ışıktır. Parlayan bir yıldızıdır ki insan onunla doğru yolu bulur. Akıl insanın Rabbine nasıl kulluk edeceğini öğretir. İnsan akıl sayesinde başta insan olmak üzere tüm varlılarla olan ilişiksine vahyin gösterdi kriterlere göre düzenleye bilir. Akıl asrısaadetten gönümüze kadar gelen rivayetlerin yanlışlarından doğrularını ayrıt etmeyi sağlar. Kısacası akıl insanın dünya ve ahret hayatının ilahi vahiy doğrultusunda düzene koymayı sağlayan hakiki mürşittir. ${ }^{19}$ Ancak özellikle tevile karşı tutumu bu sözlerini gölgede bırakmaktadır.

\section{Nassin Tevili Meselesi}

Orta Asya İdil-Ural ve Doğu Türkistan bölgelerindeki yenilikçi hareketinin akıl vahiy ilişkisi konusundaki temel hareket noktası, asırlardır kendi halkları arasında yaşanmakta olan dinî anlayışın dar kalıplarını ve yeni ortaya çıkan ilimlerle ilgili taassubu bertaraf etmektir. Çünkü onların kafasında İslam dünyasının bütününde yaşanan gerek ilmî gerekse teknolojik gerilemenin ortadan kaldırılması gibi bir problem vardı. Bu problemin çözüme kavuşturulması için en iyi çıkış noktası ise mevcut "din" ve "ilim" anlayışının doğrudan Kuran ve sünnete hatta İslam'ın ilk asırlardaki yapısına, yani selef ulemasına dayanarak yeniden yorumlanmasıdır.

Akıl vahiy ilişkisi konusunda ortaya çıkan başka bir problem ise akla aykırı gibi görünen nasların durumudur. Bu konuda yenilikçilerin bir kısmı, mutlak nakli tevil etmekten çok aklın idrakten aciz olduğunu öne süren Kursavi'yi takip etmektedir. Meyan Abdülevvel Gıfârîî ${ }^{20}$ ve Musa Carullah, bu görüşe sahiptir. Örneğin Carullah, tevilin "lazım" olarak nitelenmesine karşı çıkarak onun "caiz ve mümkün" olduğunu, fakat tevil etmek yerine susmanın daha makbul olacağını ifade etmektedir. ${ }^{21}$ Sabit b. Abdulbaki Damolla ise Allah Teâlâ'nın sıfatları ile ilgili ayetlerin tevili konusunda haleflerin haklı olduğunu savunmaktadır. ${ }^{22}$ Ancak tevile karşı çıkan bu yenilikçiler de mutlak olarak karşı çıkmamaktadır. Mesela,

Musa Carullah, Rizâeddin b. Fahreddin'in Dini ve Íctimai Meseleler kitabındaki "tevil lazımdır" sözünden hareketle aynı düşünceleri savunmaktadır. Yenilikçilerden Zakir Ayohanov ile Muhammed Hanefi Muzaffer de Carullah'ın görüşüne

18 Bu konuyla ilgili bkz. İbrahim Maraş, Türk Dünyası..., s. 125-128.

19 Sabit b. Abdülbaki, el-Kaside...s. 9-10.

20 Meyan Abdülevvel Gıfârî “Akıl ile Nakil Meselesi” Şura, 1910, 3/8, s. 228-229.

21 Musa Carullah, Mülâhaza, Petersburg, 1914, s. 11-12.

22 Sabit b. Abdulbaki, Akaid ...i, s. 6 
iştirak ederek, "caizdir"23 demenin daha uygun olacağını söylemektedirler. Mercânî, Rızâeddin b. Fahreddin gibi yenilikçiler ise nassın tevilinden yanadır ${ }^{24}$. Abdullah Bûbî ve Şemseddin Kültesî de, aynı şekilde, aklın nakilden önce geldiği ve akla aykırı gibi görünen nassın tevil edilebileceği ${ }^{25}$ kanaatindedirler. Özellikle Rızâeddin b. Fahreddin, geçmişte tevile başvurulmayan konularda tevil olabileceği gibi, yanlışlığı ortaya çıkmış teviller yerine yeni tevillerin yapılabileceğini savunmaktadır. Buradaki ihtilaf, tevile verilen anlamlardan kaynaklanmaktadır. Rızâeddin b. Fahreddin tevili meşhur 1stılah anlamıyla söze "zahirinden başka bir anlam vermek" 26 olarak tanımlarken, Musa Carullah buna karşı çıkmakta ve tevili, Kuran'ın kendi bütünlüğü içerisindeki 1stılah anlamı olarak kabul ettiği, "sözün zahirini tahkik etmek" ${ }^{27}$ olarak kabul etmektedir. Musa Carullah’1 bu görüşe iten esas sebep, İslam düşüncesi geleneğinde bu tarz tevillerin çok olması ve bu tevilleri yapan kelamcıların, söz konusu tevillerle vardıkları fikirleri kabul etmeyenleri ehl-i sünnet dişında mütalaa etmeleri veya tekfir etmeleridir. ${ }^{28}$ Zira Musa Carullah'a göre, Mercânî’den beri yenilikçilerin 1srarla savunduğu, müphem delillerle ortaya konulan sorunların itikâdî meseleler içerisine sokulması tamamen gereksiz ve yanlıştır. ${ }^{29}$

Musa Carullah, bu ayrımı yapmakla da yetinmeyerek yeni bir metod da önermektedir. Ona göre; zarûrîliği kesin olarak bilinen şeylere dinde yeri olduğunu ispat için ayrıca delil getirmeye çalışmak yanlıştır. Hatta getirilen bu delillerin davaya mutabık kalması şarttır. Mesela; caizliği kesin ve açık olan şeylere ahad haberlerle delil getirmek hatalıdır. İnsanları hayatın zaruretleri konusunda tereddüde, şüpheye düşürmeye vesile olacak şeylerden kaçınılmalıdır. Çünkü o şeyin gerekliliği daha açık bir şekilde daha kuvvetli naslarda mevcuttur. Carullah, burada, dar kalıpları aşarak, zamanın şartları icabı olarak ortaya çıkan hakiki ihtiyaçları, dine tatbik etmek hülyasıyla hadislere ve fetva kitaplarına bakarak çözmeye çalışmak yerine, usûl-i şer'iyyeye ve Kuran'a dönerek çözmeyi önermektedir. ${ }^{30}$

23 Zakir Ayohanov, "Dinî ve İçtimaî Meseleler İsimli Kitabının İntikâd ve Takriz”, Şûra 1915/5, s. 139; ayrIca bkz.İbrahim Maraş, Türk Dünyast...., s. 125-128.

24 Şehabeddin Mercânî, Nâzûratü'l-Hakk..., s. 119

25 İbrahim Maraş, Türk Dünyast..., s. 128; Abdullah Bûbî, Terakki-i Fünûn ve Maarif Dinsi liği Mucip mi? Kazan 1902,s. 11-15; ayrıca bkz., Rıfat Suyargulov, İdil-Ural Bölgesi D şünürlerinden Ziyaeddin Kemali ve Kelami Görüşleri, Ankara Ü. Sosyal Bilimler Enstitüsü Yükske Lisans Tezi, Ankara 2012

26 İbrahim Maraş, Türk Dünyası ...,s. 128.

27 M. Carullah, Mülâhaza, s. 12.

28 M. Carullah, Edebiyat-ı Arabiye, Kazan, trhs. s. 9-10.

29 M. Carullah, Edebiyât-ı ..., s. 12.

$30 \mathrm{Bu}$ konuda fazla bilgi için bkz. Musa Carullah, Edebiyât-ı..., s. 12-16; ayrıca bkz. İbrahim Maraş, Türk Dünyası..., s. 125-128. 
Sabit Damolla'nın Tevil konusundaki düşünce ve fikirleri daha ziyade Musa Carullah çizgisindedir. O da Carullah gibi tevil yapılmaması eğilimindedir. Sabit Damolla bu hususta ne Mu'tezile'nin ne de Maturidiye'nin görüşünü benimsemektedir. Bu konuda en uygun hareket metodu ona göre Eş'arilerin tutumudur:

Şevkani'nin "Neylu'l-Evtar” adlı eserinde, hadislerde söz konusu edilen Nü$\mathrm{zul}^{31}$ ile ilgili olarak Müslüman Kelam âlimlerinin tevili konusunda oldukça uzun uzadıya ele almışlardır. Gerçi bu konuda rivayet olarak gelen hadisler, birçok mutezile ulemasınca inkâr edilmiştir. Hâlbuki bu konuda doğru olan yol, Zühri'nin, Mekhul'un, Süfyan Sevri'nin, Leys'in, Hammad b. Zeyd'in, Evzai'nin, Abdullah b. Mübarek'in ve Malik, Şafii, Ebu Hanife ve Ahmed b. Hanbel gibi dört mezhep imamlarıyla bunlar dişındaki diğer âlimlerin (Allah hepsinden de razı olsun) görüşü ve yoludur. Çünkü söz konusu olan bu ilim sahipleri nüzul hadisini (ve benzerlerini), herhangi bir tevil yoluna gitmeden nasslarda nasıl gelmişse, aynen, hiçbir keyfiyete gitmeksizin dile getirmişler ve savunmuşlardır. Evzai’nin dediğine göre Mekhul ile Zühri: "Bu hadisleri geldiği şekliyle devam ettirin" derlermiş. Malik b. Enes, Evzai, Süfyan b. Said, Süfyan b. Uyeyne ve Ma'mer b. Raşid'den sıfatlarla ilgili olarak yaptığımız rivayete göre onların hepsi de, nüzul ile ilgili hadis, “yüce Allah Âdem'in kendi suretinde yarattı" anlamındaki hadis ve "Allah ayağını cehenneme girdirir" anlamındaki hadisler gibi ne türden bir hadis gelmişse, onları aynen oldığı gibi kendi manalarıyla aktardıklarını rivayet etmiştik. Zaten İbn Aldulberr'in 'Camiu Beyani'1İlm" adlı eserinde de bu şekilde gelmiştir. ${ }^{32}$

Şu halde Damolla’ya göre Allah Teâlâ akılla bilinen şeylere kıyaslanamaz, O hissi şeylere benzemez, lafız ve ifadeler onu kuşatmaktan zayıftır. Akıl ve düşünce ile onun şöyle ya da böyle olduğu tasavvur edilemez. Bununla birlikte Allah Teâlâ kendine birçok sıfatlar isnat etmiştir. Peygamber (s.av) de Allah Teâlâ'yı birçok sıfatlarla tavsif etmiştir. Bu sıfatları tevilsiz bir şekilde Allah Teâlâ'nın zatı kutsiyet sıfatına layık ve münasip, zatının irade ettiği manada olduğuna iman edip teslim ve tefviz eylemek, selef salih ve müçtehitlerin takip ettiği en güzel yoldur. ${ }^{33}$

\section{Tevhit Anlayışı}

Sabit b. Abdulbaki'nin üzerinde en fazla durduğu ve temellendirmeye çalışt1ğ1 ana tez her zaman tevhit ilkesi olmuştur. Zira yenilikçi-selefi anlayışın en dikkat çeken özelliği tevhit anlayışını ilk dönem selefin anlayışına uygun bir şekle kavuşturmaktır. Zira Müslümanlar her konuda olduğu gibi bunda da Bidate dalmışlardır.

31 Nüzul hadisi olarak anlatılan habere göre güya Allah gök yer semasına inmektedir ki Eş'ari bunu el-İbane'de zikredip kabul etmektedir.

32 Sabit b. Abdülbaki, el-Kaside..., s. 3.

33 Sabit b. Abdülbaki,, Beyanu's-Sünne, Delhi, Şahicihan, mahbubi'l-matabi , 1932, s. 3. 
O bu konuda ne kadar hassas olduğunu göstermek amacıyla genç nesil için Akaid Cevheri adlı bir de eser kaleme almıştır.

Daha sonra kanımın döküldüğü ve göbek bağımın kesildiği doğduğum yer dünyanın cenneti ve cennet ehli gibi güzel ahlak sahibi insanların yaşadığı Doğu Türkistan'a dönmeden önce, vahyin ilk indiği, İslam'ın ilk mekanından, milli dostlarım ve kan kardeşlerim için, içmekle bitmeyecek, yemekle tükenmeyecek, bütün canlara gıda, hastalara şifa bir çeşit hurma ve zemzem hediye etmek hayalımdan geçti. Bu sebeple toplum yararını düşünerek Türk dili ile kaleme alınan "İslam kanunu" adı kitabımı bastırıp hediye etmeye karar verdim. Ancak baktım ki, seyahatim çok uzayacak, iki defter halındaki kitabı yeniden düzenleyip bastırmak hayli zaman alacaktır. Bu nedenle halis tevhit akidesinin genç nesillerimize, çocuklarımıza öğretile bilmesi düşüncesiyle soru ve cevap şeklinde "akaid cevheri” adlı bu risaleyi hazırladım. ${ }^{34}$

Damolla Akaid risalesinde tevhit akidesinin önemini vurgulamaya özel bir önem vermektedir. O, Tevhid'in zıddı olarak gördüğü şirkten kaçınmanın Müslümanların en önemli vazifesi olduğunu belirtmektedir. ${ }^{35}$ Damolla Akaid Cevheri adlı eserinde akaid ilkelerini soru-cevap şeklinde ele almaktadır. Burada ilk olarak "Allah Teâlâ'nın kullarına emrettiği güzelliklerin en kutsal olanı nedir?" sorusunu sorarak söze başlamaktadır. Cevabı ise elbette Tevhit olacaktır. Tevhit'ten ne anladığını da şu şekilde ortaya koymaktadır: "Tevhit ise Allah Teâlâ'yı zat, sıfat ve fiillerinde tek olduğuna dil ile şahitlik etmek, amel ve ibadette ona hiçbir şeyi ortak koşmamaktır. Yani amel ve ibadetleri onun zati ulûhiyet sıfatına mahsus kılmaktır. Bütün peygamberlerin Allah katından getirdikleri din işte bu dindir. Allah Teâlâ'nın "Halbuki onlar sadece dini Allah'a özgü k1larak ibadet etmeleri emredilmiştir" mealindeki ayeti ve peygamber (s.a.v)in 'Biz peygamberler zümresinin dini tekbir dindir.' hadisi bunun delilidir.

Burada ikinci soru ise tevhidin zıddı olan şirkin ne olduğu hususundadır. "Allah Teâlâ'nın kullarına yasakladığı en çirkin şey nedir? Şirktir. Şirk ise Allah Teâlâ'ya başka şeyleri ibadette ortak kılmaktır. Şirk bütün kötülüklerin başıdır. Allah katında şirkten daha büyük günah yoktur. Bu sebepten Allah Teâlâ şirki asla bağışlamaz. Şirkten başka günahları dilediği kimse için bağışlar."

Bundan sonra tevhidle bağlantılı olarak kulların yapmakla yükümülü oldukları dört şeyden bahsedilir. Bunlar Allah’ı ve Peygamberini delil ve burhanlarıyla bilmek, amel ve ibadetleri Hz. Peygamber'in gösterdiği şekilde yerine getirmek, insan-

34 Sabit b. Abdülbaki, Akaid..., s. 6

35 Sabit b. Abdülbaki, Akaid..., s. 7

36 Sabit b. Abdülbaki, Akaid...,, s. 8. 
ları iman ve ibadete davet etmek (emri bi'l-ma'ruf nehy-i ani'l-münker) ve insanları iman ve ibadete davet etmede sayfa karşılaştıkları her türlü zorluklara sabır göstermektir. ${ }^{37}$ Onun tevhid ilkesine bağlılığı o kadar güçlüdür ki bu anlayışa göre hiçbir varlık, Allah Teâlâ var etmezse asla var olmaz. Her varlık Allah Teâlâ'nın icat etmesiyle var olur. Bir şeyi yaratmak, var etmek güzeldir. Ama varlığın kendisine nispetle bazıları güzel bazıları çirkindir. Bu mesele sağlam iman ve parlak marifetten, Allah Teâlâ'nın tevhidini ve rububiyyetini kabul etmenin esaslarındandır. Çünkü Allah Teâlâ "وكان أمر اله قدرا مقدور ا. وخلق كل شيء فقدره تقدير" buyurmuştur.38

Damolla, kullara ilk vacip olanın tevhit olduğunu dile getirdikten sonra Tevhid'in tanımını yapmaktadır: "Tevhit Allah Teâlâ'yı bir bilmek, bütün amel ve ibadetleri sadece ona yapmak, içten inanarak tam inkıyatla (boyun eğerek) teslim olmak ve zahiri ve batını şirkten külliyen kurtulmaktır."39 Daha sonra Allah'a boyun eğmenin (ınkıyat) üç merhalede gerçekleştiğini açıklamaktadır. Bunların ilki İslam, ikincisi iman üçüncü mertebe ise ihsandır. Dikkat edildiğinde bu üç aşama Cibril hadisinde belirtildiği şekilde sıralanmıştır.

\section{Iman}

Damolla'ya göre tevhit ilkesinden sonra en önemli sırada iman gelmektedir. Zira o, tevhitten sonra kulların yapmakla yükümlü oldukları (vacip)in "İman ve küfür, hidayet ve dalalet arasındaki farkı bilmek" olduğunu söylemektedir. Çünkü kul iman nedir, hidayet nedir bilmezse küfür ve dalaletin ne olduğunu da bilemez. Ayr1ca onun diline ilimsiz ve itikatsız bir biçimde bazen tevhit kelimesi, bazen de küfür kelimesi cari olur. İlim ve marifet bu mertebedeki kişiye hiçbir amel ibadet yararı sağlamaz. Damolla bu sözleriyle hakiki iman olmadan gerçekleşen amel ve ibadetlerin boşa gittiğini belirterek klasik Ehl-i Sünnet'in iman olmadan ameller batıl olur düşüncesini kabul ettiği anlaşılmaktadır. Zira Damolla'ya göre tevhit ve iman asıl, amel ve ibadet fer'idir. Bundan dolayı örneğin kullara tevhitten sonra vacip olan namza, oruç, hac ve zekat gibi ibadetleri onların hükümlerini yerine getirebilecek derecede bilmenin vacip olduğunu söylemekte ve bilgiye işaret etmektedir. ${ }^{40}$ Damolla daha sonra yine mukallidin imanı meselesine gelerek yine kelamdaki bilgi meselesine işaret etmektedir: Farz-1 ayn olan ilim ve marifete sahip olmadığı halde, Müslüman olduğunu iddia eden kişinin hükmü nedir? Sorusuna Damolla şu şekilde cevap vermenin uygun olacağı kanaatindedir: “O kişinin ‘Ben Müslümanım’ demesinden başka herhangi bir yararı yoktur. Dünyada zahirine hükmedilir ve kafirlerden

\footnotetext{
Sabit b. Abdülbaki, Akaid...,, s. 8.

Sabit b. Abdülbaki, Beyan...,s. 14.

Sabit b. Abdülbaki, Akaid...,,,s. 10.

40 Sabit b. Abdülbaki, Akaid...,,s. 11.
} 
alınan cizye onlardan alınmaz. Ama ahirette bu İslamı ile cennet derecesine ulaşması zordur. Çünkü Allah Teâlâ’ya yakınlık marifet sahip olduğu derecededir."41

Damolla iman ilkesiyle bağlantılı olarak İslam, iman ve ihsan tanımlamalarını yapmayı da ihmal etmemektedir. O bu tanımlamaları yine meşhur Cibril hadisine uygun şekilde yapmaktadır: İslam'ın rüknü beştir. 1. Allah Teâlâ'dan başka ibadete layık hak ilah yoktur. İbadete layık olan sadece Allah'tır. Muhammed (s.a.v) Allah'ın kulu ve bütün insanlara gönderilen nebi ve elçisi olduğuna içten inanarak dil ile şahitlik etmektir. 2. Namazı dosdoğru kılmak. 3. Zekât vermek. 4.Ramazan ayında oruç tutmak. 5. Gücü yeten kişinin ömründe bir kere de olsa hac yapmasıdır. İman yetmiş küsür daldan oluşur. En üstte olan içten inanarak Allah'tan başka hakiki ilah olmadığına şahitlik etmektir. En alt seviyedeki ise yolda yürüyen insanlara zarar verecek şeylerin kaldırılmasıdır. Utanma duygusuna sahip olmak da imandan bir daldır. İmanın rüknü altıdır. 1. Allah Teâlâ'ya iman. 2. Allah'ın meleklerine iman. 3. Allah'ın kitaplarına iman. 4. Allah'ın peygamberlerine inanmak ve tasdik etmek. 5. Kıyamet gününün gerçek olduğuna inanmak. 6. Kadere inanmak. Yani iyilik ve kötülüğün yaratıcısı Allah’tır. Her iyilik ve kötülüğün Allah’tan olduğuna inanmaktır. İhsan Allah Teâlâ'ya onu görürcesine ibadet etmektir. Çünkü kul Allah'1 görmese de Allah kulu görür. ${ }^{42}$

İman ve bununla bağlantılı olarak İslam ve İhsan'ın şart ve koşullarını açıkladıktan sonra imanın ne olduğu, onun mahiyetini açıklamya çalışmaktadır. Ona göre iman kalp ile tasdik, dil ile ikrardır. Bu yönüyle onun kavl-i meşhur'u kabul ettiği, ancak imanı, "iman kalp ile tasdik ettiğini dil ile ikrardır" tanımlamakla da onun esasen kalpteki tasdikin asıl dil ile ikrarın ise fer' olduğunu kabul eden Maturidi ve Eş’ari’nin görüşlerini kabul ettiği tespit edilmektedir. Ancak Damolla imanın yaratma yönüyle (Tevfik ve hidayet) Allah'a, kazanma/kesb yönüyle de (ikrar ve tasdik) kula ait bir amel olduğunu söylemektedir. Birincisi mahluk değilken ikincisi mahluktur. $^{43}$ İmanda artma ve eksilme olup olmadığı meselesini ise şu şekilde ortaya koymaktadir:

İmanda inanılması gereken şeyler/esaslar (mu'minun bih ve musaddakun bih) bakımından herhangi bir artma ve eksilme olmamasına rağmen, tasdik, kesinlik ve kalbi huzur itibariyle iman artar ve eksilir. Bu görüşünün İmam Azama nispet edilen el-Fikhu'l-Ekber adlı eserden ve İmam Ebu Mansur Maturidi’nin ve İmam Pezdevi’nin şerhinden alındığını da dile getirmektedir. ${ }^{44}$

41 Sabit b. Abdülbaki, Akaid...,,,s. 11

42 Sabit b. Abdülbaki, Akaid...,,s. 10.

43 Sabit b. Abdülbaki, Akaid...,,,s. 15.

44 Sabit b. Abdülbaki, Akaid...,,,s. 15. 
Müellif bundan sonra bir mü'minin fisk ve günah ile küfre düşmeyeceğini, belirterek ümmetin asilerinin tevhidi dürüst olduğu ve haramı helal, helalin de haram olduğunu düşünmediği sürece mümin oldukların1" ${ }^{45}$, böylece de "mümin günah işlemekle imandan çıkmaz" demektedir. Ancak bize göre önceki sayfalarda neredeyse amel ile imanı ayrılmaz parçalar olarak gören yaklaşımıyla çelişmiş olmaktadır. Onun bu sözleri incelendiğinde sadece dille kelime-i Tevhidi söylemenin kişiye fayda sağlamayacağını belirtmek suretiyle muhtemelen amelin imandan bir cüz olduğunu ortaya koymaya çalışmaktadır. İman bağlamında tasdik’i ön plana çıkarmaktadır. Tasdik ona göre hucurat suresi 14 . Ve 15. ayetlerde ifade edildiği üzere ${ }^{46}$ imanın amellerle bütünleşmiş ve kalbe inmiş durumundan ibarettir: "Bu ayet ve hadislerden, tevhidin fazileti ve onun sevabının büyüklüğü anlaşılmaktadır. Ancak ayet ve hadisler incelenip mütalaa edilirse, sadece dille " للا إله إلا الها demenin de hiçbir önemi olmadığı açıkça ortaya çıkar. O halde imanı dürüst, takva ve tevhidi samimi bir şekilde benimseyerek ve tasdiki de içten dillendirerek emrolunanlara iman getirmek gerekir. Onları bilmek ve nelerin şirk olduğunu, nelerin küfre götüreceğini iyi anlamak gerçekten iman edilirse, böyle iman ancak sahibini kurtarabilecektir. Damolla bu konuyla bağlantılı olarak, tevbe etmeden ölen fasık birisinin (mürtekibu'l-kebira) imanla gittiyse Allah dilerse affedilebileceğini, dilemezse cehenneme gideceğini veyahut birisinin şefaati ile affedilebileceğini belirtmektedir. ${ }^{47}$ Bilindiği üzere fasık büyük günah işleyen birisine denmektedir. Bu konu iman-amelden bir cüz müdür değil midir? Konusuyla bağlantılı olup bu konuda ekoller birbirlerinden ayrılmışlardır. Hariciler, Selefiye ve Mu’tezile amelin imandan bir cüz olduğu belirtmekte ancak hariciler büyük günah ileyenin ebedi cehennemlik olduğunu, Mu’tezile ise tevbe etmeden ölürse bu kişinin ebedi cehennemde kalacağı, ancak dünyada tevbe edene kadar iki mekandan birisnde "el_menzile beyne'l-menzileteyn" kalacağını belirtmektedirler. Mürcie ise böyle birisinin Allah’a havale edilemsi gerektiğini bildirmişlerdir. Zira onlara göre iman amelden bir cüz değildir. Ehl-i sünnet'in Mürcie'nin bu görüşünü aldığı açıkça görülmektedr.

Damolla, İman ve hidayetin Allah Teâlâ'nın bir lütfu ve ikramı, küfür ve dalaletin ise Allah Teâlâ'nın adaleti olduğunu belirtmektedir. Ancak bunun devamında sarf ettiği sözleriyle tam anlamıyla cebri bir anlayışa sahip olduğunu tespit etmekte-

45 Sabit b. Abdülbaki, Akaid...,,s. 15.

4614 - Bedevîler "inandik" dediler. De ki: Siz iman etmediniz ama "İslâm olduk." deyin. Henüz iman kalplerinize yerleşmedi. Ĕger Allah'a ve Resulüne itaat ederseniz, Allah işlerinizden hiçbir şeyi eksiltmez. Çünkü Allah çok bağışlayan, çok merhamet edendir. 15 - Gerçek müminler ancak Allah'a ve Resulüne iman eden, ondan sonra asla şüpheye düşmeyen, Allah yolunda mallarıyla ve canlartyla savaşanlardır. İşte doğrular ancak onlardir.

47 Sabit b. Abdülbaki, Akaid...,,,s. 18. 
yiz: "Lütuf ve adalet Allah Teâlâ'nın sıfatlarındandır. Allah Teâlâ zulüm ve adaletsizlikle vasıflanmaz. Allah Teâlâ'nın takdir ve tedbirine itiraz etmeden, teslimiyetle ona havale etmek gerekir. Ne sebepten şuna iman ve hidayet verdi ve buna küfür ve dalalet verdi, niçin şunu aziz kıldı ve bunu alçak yaptı, bunu ne sebepten sıddık yaptı onu ne sebepten zındık kıldı; diye düşünülmez ve dile de getirilmez. "O yaptığından sorgulanmaz aksine onları yaptıklarından sorgular." 48 "Fazl ve ikram Allah'tandır, dilediğine verir" ${ }^{\prime 99}$ mealindeki ayetler bunun delilidir." ${ }^{50}$

Esasen bu tür bir iman anlayışı selefiye için karakteristik bir özelliktir: Tam anlamıyla sorgulamaksızın mutlak itaat ve boyun eğme. Bu hususu Beyanu'sSünne'de şu şekilde açıklamaktadır: Allah Teâlâ'nın İbrahim (a.s)i dost edindiğine ve Musa (a.s) ile konuştuğuna içten tasdik ederiz ve bütün teslimiyetle iman ederiz. Tüm meleklere, peygamberlere indirilen tüm kitaplara gönülden iman ederiz. Peygamberlerin apaçı hak yol üzerinde olduğuna şahitlik ederiz. Ehli kıblenin hepsini, peygamber (s.a.v)in Allah katından getirdiklerini kabul edip tasdik ettikleri sürece Müslüman ve mümin olarak kabul ederiz. Allah Teâlâ'nın zatı ile tartışmalara girmeyiz. Allah Teâlâ'nın zatı ile ilgili fazla tefekkür etmeyiz. Allah Teâlâ " ولا تقف ما "ليس للك به علم hazretleri, Allah Teâlâ'nın zatından söz etmeye hiç kimsenin liyakati yoktur buyurmuş. Herkes Allah Teâlâ'yı kendi nefsini vasıflandırdığı sıfatlarla vasıflandırsın, demiştir. Allah Teâlâ'nın mukaddes dininde ve Kuran Kerim hakkında da tartışmamalı, Kuran tüm âlemlere rablik eden Allah Teâlâ'nın kelam kadimesidir, Cebrail (a.s) vasıtasıyla Muhammed (s.a.v)e indirmiştir. Mahlûkların kelamından hiçbir şeyin ona benzemediğine inanıyoruz. Kuran'ı mahlûk dememeli, Müslüman cemaatine muhalefet etmemeliyiz. ${ }^{51}$ Damolla kelamla başlayan ilim hayatında bu tür teslimiyetçi iman aşamasına kolay kolay gelmediğini bundan da asla vazgeçmiyeceğini açıklamaktadır. $^{52}$

Damolla meleklerin kimler olduğu konusunda Ehl-i sünnet inancındaki meleklerle ilgili, onların itaatkar oldukları, her birinin çeşitli görevleri olduğu, ne emredilirlerse onları yaptıkları v.b. düşünce ve fikirleri kabul ettiğini açıklamaktadır. ${ }^{53}$ Ancak kendisinin yenilikçi-selefi anlayışına uygun olarak meleklerin kanatlarıyla ilgili tartı̧̧ma dikkatimizi çekmektedir. Bunu aktarmak istiyoruz: "Meleklerin ikişer, üçer, dörder ve daha fazla kanatları vardır. Onlar zat ve şekilleri mahsus (hissedilir)

\footnotetext{
Enbiya 21,23.

Al-i İmran 3,26.

Sabit b. Abdülbaki, Akaid...,,,s. 15.

Sabit b. Abdülbaki,, Beyan ..., s. 15.

Sabit b. Abdülbaki, el-Kaside..., s. 2

Sabit b. Abdülbaki, Akaid...,,, s. 12.
} 
mahlûkların zat ve sıfatlarından farklıdır. Kanatları uçan canavarların kanatlarına da benzemez. Aksine kendilerine layık ve kendi âlemine muvafik Allah Teâlâ'nın takdir ve tedbirine mutabık kendi ortamlarına münasip zat, şekil ve kanatlara sahiptirler. Onların zatı, şekilleri ve kanatlarından bahsedilmez. Çünkü bunlar gayb âlemindedir, bu âlemdekilere kiyaslanamaz." ${ }^{54}$

Damolla bundan sonra Allah'ın kitaplarının neler olduğunu sıralamaktadır: Bunlar Tevrat, Zebur, İncil ve Kuran Kerim'dir. Ona göre bu kitaplardan değişmeyen tahrif olmayan sadece Kuran'dır: Onun hükmü kıyamete kadar devam edecektir. Damolla'ya göre Kuran mahlûk değildir... O, Ahir zamanda kullarının dillerinden ve Mushafların sayfalarından kaldırıldığında yine Allah Teâlâ katına gider. Buna delil olarak ta "biz zikri/Kuranı indirdik yine biz onu koruyacağı" tedir. $^{56}$

\section{6.İnsan Fiilleri: İrade, İstita'at, ecel, rızık, kaza ve kader}

Damolla'nın insan fiillerine ilişkin görüşlerinin Maturidi çizgisinde olduğunu söylememiz mümkün gözükmektedir. Bu konuda elbette en önde kader konusundaki düşünceleri ön planda durmaktadır. Bunu daha sonra istitaa'at konusu takip etmektedir. Rızık ve ecel konuları da bu bağlamda ele alınmaktadır. O, açık ve net bir şekilde iyilik ve kötülüğü takdir edenin Allah, işleyen ve kazananın ise kul olduğunu belirtmektedir. Ona göre kul iyiliği ve kötülüğü işlemekte özgür irade sahibi, yani seçme hakkına sahiptir. Buna delil olarak ta "sonra ona kötülüğü ve iyiliği ilham etti ${ }^{\prime 57}$ mealindeki ayetini vermektedir. ${ }^{58} \mathrm{Bu}$ ifadelerinden onun Maturidilerin kulların fiilleri hususundaki kesb ilkesini kabul ettiğini anlamaktayız. Bu noktada kula cüz'i irade verilmiş ve bu cüz'i irade konusunda kul tam anlamıyla özgür bırakılmıştır. Bilindiği üzere Eş'ariler'in kesb teorisinde kulun cüz'i iradesi Allah'ın iradesine bağlıdır ve hür değildir. Ancak Damolla kulların, bütün amel ve fiillerini var edenin Allah Teâlâ olduğunu bunu da "Allah sizleri ve yaptıklarınızı yarattı" ${ }^{59}$ mealindeki ayetle desteklemekte, bize göre kulların cüz'i iradelerinde tam olarak hür olmadıklarını düşünmemektedir. Onun bu sözü daha ziyade Allah'ın insanın fiillerini halk yönüyle yarattı̆̆ına dair Matüridi düşüncesini yansıtmaktadır.

Damolla rızkın Sünni düşünceye göre helal ve haram olan her şeyi kapsadığını, bir kul için tespit edilmiş olan rızkın sadece o kimse tarafından alınabileceğini

\footnotetext{
Sabit b. Abdülbaki, Akaid...,,,s. 12-13.

Hicr 15, 9.

Sabit b. Abdülbaki, Akaid...,,,s. 13.

Insan 76, 3.

Sabit b. Abdülbaki, Akaid...,,,s. 16.

Saffat, 37, 96.
} 
belirttikten sonra istita'at konusunda klasik Maturidi düşüncesini yansıtan şu cümleleri ortaya koymaktadır: "Bilinmeli ki istitaat iki çeşittir. 1. fiilin var olmasını sağlayan istitaat. Bu istitaat mahlûkun sıfatı değildir. Fiilden ayırt edilmesi imkânsız olan bu istitaat fiilden ne önce ne de sonradır. Tevfik gibi fiilin var oluşuna medardır. 2 . Esenlik, sağlık ve sıhhat, hastalıklardan uzak olmak, gücü yeten olmak gibidir. Kulların sıfatı olan bu istitaat fiilden önce ve teklife medardır. "Allah kimseyi gücü yetmeyeceği bir şeye emretmez"60; "gücünüzün yettiği ölçüde Allah’tan sakının"61 "o hacc1, yapmaya gücü yeten için"62 mealindeki ayetlerde geçen istitaat bu kabildendir. Kulun fiilini Allah yaratır. Kul kesip itibariyle mükelleftir.” Bilindiği üzere Mu’tezile insanın bütün fiilerindeki istita'atinin fiilden önce olduğunu Eş'ariler ise fiille beraber olduğunu belirtirken Maturidiler orta bir yol takip ederek istita'at'i ikiye ayırmak suretiyle orta bir yol bulmaya çalışmışlardır.

Damolla ömür ve ecel konusunda da klasik Sünni düşünceyi yansıtmak suretiyle, her kişi için biçilen ömrün tek olduğunu, kişi hangi şekilde, kesilerek, yükseklerden atılarak, yanarak, boğularak ölürse ölsün kendi eceli ile ölmüş olduğunu, ecelin gecikmediğini ve erkene de alınamayacağını "Onların eceli gelince bir an geç kalmayacak ve erkene de alınmayacaktır" ayetinin de buna delil olduğunu ifade etmiştir. Oysa Mu'tezile'ye göre ecel iki türlüdür: Ecel-i Kaza ve Ecel-i Müsemma. Ecel-i Müsemma ömürdür ki bu En'am suresi 2. ayetinde de ayette de belirtildiği üzere artıp eksilebilmektedir. ${ }^{63}$

Damolla'nın kader hususunda söylediği şu sözlerle tam anlamıyla cebri bir anlayışa sahip olduğu söylenebilir. Zira bu sözlerde onun, Levh-i Mahfuz ve Kalem kavramlarını da kader bağlamında değerlendirerek katı bir anlayışa sahip olduğunu gözlemlemekteyiz. Ona göre, Levh ile kaleme ve levhte yazılanların hepsine iman etmek gerekir. Allah Teâlâ'nın olacak diye yazdıkları için, bütün halk bir araya gelip hep bir ağızdan olmayacak deseler ve olmaması için mücadele etseler de olmasına engel olamazlar. Allah Teâlâ'nın yazmadığı şeyi bütün halk olacak hale getiremezler. Kıyamete kadar olacak şeyleri yazmıştır ve artık kalem kurumuştur. Yani yazılmayan şeylerin yazılması, yazılan şeylerin de silinmesi mümkün değildir. Kalem kurumamış olsaydı bunlar belki mümkün olurdu. Kaderde kula isabet etmeyecek şeyler hiçbir zaman isabet etmez. Kaderde ona isabet edecek şeyler hiçbir zaman ondan kaçamaz. Mahlûklardan kıyamete kadar olacak şeylerin olmasında, önce Allah Teâlâ bilerek, kendi meşieti ile bozulmaz bir biçimde muhkem takdir etmiştir,

60

6

62 Al-i İmran 3, 97.

63 "Sizi çamurdan yaratan, sonra size bir ecel takdir eden O'dur. Tayin edilen bir ecel de (kıyamet zamanı) O'nun katındadır. Sonra bir de şüphe ediyorsunuz." 
diye itikat etmek vaciptir. Onun hükmünü ne bozan vardır ne yok eden. Değiştiren, bir halden ikinci bir hale çevirebilecek dahi yoktur. Yer ve göklerdeki mahluklar ezelde takdir edilmiştir, artısı ya da eksiği yoktur. "Hiç yaratan bilmez mi? O, en ince işleri görüp bilmektedir, her şeyden haberdardır." (Mülk, 67 / 14) Mealindeki ayet ve "Allah Teâlâ halkın kaderlerini gökler ve yer yaratılmadan elli bin sene önce takdir etmiştir" mealindeki hadis, Allah Teâlâ'nın mahlukların kaderlerini önceden bildiğine açık delildir. Hiçbir varlık, Allah Teâlâ var etmezse asla var olmaz. Her varlık Allah Teâlâ'nın icat etmesiyle var olur. Bir şeyi yaratmak, var etmek güzeldir. Ama varlığın kendisine nispetle bazıları güzel bazıları çirkindir. Bu mesele sağlam iman ve parlak marifetten, Allah Teâlâ'nın tevhidini ve rububiyyetini kabul etmenin esaslarındandır. Çünkü Allah Teâlâ "وكان أمر الله قدرا مقدورا. وخلق كل شيء فقدره تقير" buyurmuştur. ${ }^{64}$

Damolla Kaza ve kader konusunda, Allah Teâlâ ile tartışanların hasret ve nedamete duçar olduklarını ileri sürmektedir. Ona göre kaza ve kader konusunda düşünen ve fikir yürüten, gaip ilmini araştırmak için aciz aklı ve vehim ile Allah Teâlâ'nın gizli tuttuğu sırrın peşine takılmıştır. Kader konusunda bir şeyler söyleyen yalancı olur ve günaha girmiştir. "عالم الغيب فلا يظهر على غبيه أحدا إلا من ارتضى من رسول gibi ayet ve bu manada gelen hadisler, güneş ışığı gibi açık olmasına rağmen Müslümanların hiç birine gaibi bilmeyi iddia etmek ya da falan kişi gaibi bilir demek caiz değildir. Gaibi bilmek, kudret ve kıdem gibi Allah Teâlâ'ya has sıfatlardandır. Ki bu sıfatlarla mahlûkatlardan her hangi birisini tavsif etmek doğru değildir. ${ }^{65}$

Ancak onun bu sözleriyle yetinmeyip bu konuda sarf ettiği başka ifadelerine baktığımızda kader konusunda tam anlamıyla Maturidi bakış tarzını yansıttığı sonucuna varmaktayız:

Kullar gerçekten faildirler, onların fiillerini yaratan ise sadece Allah'tır. Kul denince, mümin-kâfir, iyi-kötü, namaz kılan, oruç tutanların tamamını kapsar. Çünkü kulların bütün bu işleri yapabilme güçleri vardır. Bir de iradeleri bulunmaktadır. Onları da, onların yapacakları şeyler konusundaki kudret ve güçlerini de yaratan Allah'trr. ${ }^{66}$

Esasen çelişkili gibi görünen bu iki kader tanımlaması Damolla'nın inanç sistematiğinde tutarlı bir yapya sahiptir. Zira ona göre kadere iman meselesi iki derecelidir. Birinci derece; Allah'ın yaratmış olduğu âlemleri ezeli olan ilmiyle en iyi olarak bilendir. Zaten Allah, bu ezeli ilimle nitelenmiştir. Kaldı ki Allah, onların gerek taat ile ilgili olsun, gerek masiyetle alakalı durumları olsun hepsini bildiği gibi onla-

64 Sabit b. Abdülbaki,, Beyan..., s. 13-14.

65 Sabit b. Abdülbaki, Akaid...,,,, s. 19

66 Sabit b. Abdülbaki,,el-Akide..., s. 7. 
rın rızıklarını da ecellerini de bilir. Sonrasında yüce Allah, Levhi Mahfuz'da, tüm yarattıklarının kaderlerini de yazıp takdir etmiştir. Allah'ın ilk yarattığı şey, Kalem-

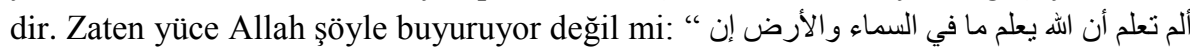
Bilmez misin ki, Allah, yerde ve gökte ne varsa bilir? $\mathrm{Bu}$, bir kitapta (levh-i mahfuzda) mevcuttur. Bu (eşya ve olayların bilgisine sahip olmak), Allah için çok kolaydır." 67 İşte bu ölçüye göre, her şeyden münezzeh olan yüce Allah'ın ilmine tabi olarak kimi yerlerde mücmel olarak, kimi yerlerde etraflı bir şekilde belirtildiği üzere hepsi de meşieti gereği Levhi Mahfuz'da yazılmıştır. Ceninin cesedi yaratılınca, ruh üflenmeden önce kendisine bir melek gönderilir. $\mathrm{Bu}$ meleğe dört şeyin yazması emri verilir ve kendisine: "Onun rızkını, ecelini, amelini, kötü biri mi yoksa iyi biti mi olacak, işte bu ve benzeri şeyleri yaz” denir. İşte kaderin bu türünü Aşırı kadercilik/Gulatı kaderi inancında olanların kabul etmedikleri, inkâr ettikleri kader türüdür.

İkinci derece: Bu, Allah’ın etkin olan, kudretini ilgilendiren oldukça kapsamlı olan meşieti/dilemesidir. Bu da “Allah'ın dilediği olur, Allah'ın dilemediği de olmaz" esasına iman etmektir. Göklerde ve yerde bir hareket ve hareketsizlik olmasın ki, orada mutlaka Allah'ın meşieti vardır. Allah'ın mülkünde ancak onun irade buyurduğu meydana gelir. Çünkü her şeyden münezzeh olan Allah, her şeye kadirdir/gücü yetendir. İster mevcut/var olan şeyler olsun, ister madum/olmayan şeyler olsun, gökte ve yer de ne kadar yaratılmışlar varsa, hepsinin yaratıcısı Allah’tır. Ondan başka bir yaratan ve ondan başka bir Rab da yoktur.

Bütün bunlarla birlikte yüce Allah, kullarına kendisine ve resullerine itaat etmelerini, hepsinin de yasaklarından ve masiyetten uzak durmalarını emir buyuruyor. Allah, muttaki olanları/Allah'ın emir ve yasakları doğrultusunda hareket edenleri, Muhsinleri, adil olanları sever. İman edip salih amel işleyenlerden razı olur. Allah kâfirleri sevmez ve Allah fasık olan toplumdan da hoşnut olmaz. Allah fahşayı/hiçbir kötülüğü emretmez. Kulları için küfürden hoşnutluk duymaz. Allah fesadı sevmez. ${ }^{68}$

İşte Damolla'ya göre kadere iman konusunda bu iki derecenin farkında olmayıp fiillerin yaratıcısının da kulların bizzat kendilerinin olduğunu söyleyenler aş1rıya gitmişler ve hadiste belirtildiği üzere ümmetin Mecusileri olma özelliğini kazanmışlardır. Ancak diğer yandan ispat ehli olarak tanımladığı bir kısım Ehl-i hadis ve selefi gruplarının da aşırıya giderek kulun "kudret ve ihtiyarının/seçim hakkının

$67 \mathrm{Hac}, 22 / 70$

68 Sabit b. Abdülbaki,,el-Akide..., s. 6-7. 
olmadığını ileri sürüdklerini belirtmektedir. Ancak müellif bunlar için yukarıda kaderi inkar edenler için kullandığı kötü tanımlamayı kullanmamaktadır. ${ }^{69}$

Bununla birlikte şunu da belirtmek gerekir ki her ne kadar kula Allah seçme hürriyeti ve kudreti vermişse de onun iman etmesi ve hidayeti Allah Teâlâ'nın lütfu ve ikramıdır. Bu elbette yukarıda da açıklandığı üzere yoktan yaratma anlamındadır. Yoksa kesb anlamında değildir. ${ }^{70}$

\section{Nübüvvet}

Damolla, Allah'ın temelde peygamber göndermek zorunda olmadığına dair Matüridi düşüncesini paylaşmak suretiyle şunları zikretmektedir: "Allah Teâlâ onları sırf merhameti, fazlı ve ikramı gereği insanlara rehberlik etsinler diye göndermiştir. Onlar müminleri cennet ve ödüllerle müjdeler, müşrik ve kâfirleri cehennem ve çekecekleri azap ile uyarır. İnsanlara din ve dünya saadeti için gerekli olan şeyleri beyan ederler." ${ }^{\text {71 }}$ Peygamberlerin çeşitli mucizelerle desteklendiğini de sözlerine eklemektedir. Bu düşünce bilindiği üzere Maturidi bakış açısını yansıtmaktadır. Husun-kubuh anlayışına bağlı olan bu anlayışta Allah Peygamber göndermese bile kişi aklıyla Allah'a itaat etmeyi, iyilik/salih amel yapmayı ve kötülüklerden kaçınmayı da bulabilirdi. Bundan dolayı Maturidilerde Mutezilede olduğu gibi Allah'ın peygamber göndermesi Onun merhameti ve lütfu gereğidir. Oysa Eş'ariler'de akıl vahiy olmadan iyinin ve kötünün arasını ayırt etme melekesine sahip olmadığından Allah'ın insanı sorumlu tutabilmesi için peygamber göndermesi gereklidir.

Damolla, Peygamberlerin sıfatların anlatırken onların ne peygamberlik öncesinde ne de peygamberlik sonrasında herhangi bir şekilde "Allah Teâlâ'nın nehyettiklerinin hiçbirini yapmazlar, yalan söylemezler, gaflete düşmezler, yüce mertebelerine zarar vermeyecek ve peygamberliğe dair ayıp sayılmayacak ve noksanlık getirmeyecek fiilleri yaparlar.” Demekle klasik Sünni düşüncesini yansıtmaktadır. Yani onlar günahtan her zaman için pak ve masumdurlar. ${ }^{72}$

\section{Sonuç}

XIX. yy. tecdid hareketleri Türkiye, Mısır ve Hindistan merkezli olarak başlamış ve diğer tüm İslam coğrafyasını etkilemiştir. Mısır'da Cemalettin Efgani ile başlayan tecdid hareketlerini öğrencisi Muhammed Abduh devam etttirmiş̧ir. Efgani ve Abduh'ta kelama karşı ciddi anlamda bir karşı çıkış söz konusu olmamıştır. Ancak Abduh'un öğrencisi M. Reşid Rıza ile durum değişmiştir. Reşid Rıza yenile-

Sabit b. Abdülbaki,,el-Akide..., s. 7.

Bkz. Sabit b. Abdülbaki, Akaid...,,, s. 15.

Sabit b. Abdülbaki, Akaid...,,,, s. 14

Sabit b. Abdülbaki, Akaid...,,, s. 14. 
me hareketinin seyrini değiştirmiş ve adeta kelam karşıtı yenilikçi-selefi bir karakter kazanmasına yol açmıştır. İşte Türkiye ve kısmen de Hindistan (Pakistan) hariç diğer İslam ülkelerindeki yenileme hareketleri kelam karşıtlığı temelinde gelişmiştir. Orta Asya'daki yenileme hareketleri de aynı düzlemde gelişmiştir. Damolla Sabit b. Abdülbaki de Doğu Türkistan yenilikçileri arasında değerlendirilmiştir. Ancak onun da Reşid Rıza'dan büyük ölçüde etkilendiği tespit edilmektedir. Bunu bizzat kendisi de eserlerinde dile getirmektedir. Bir ara Doğu Türkistan İslam Cumhuriyeti'nin de Devlet Başkanlığını da yürüten Damolla Sabit yaptığı yenileme hareketinde sürekli kelam karşıtlığ içerisine girmiş ve tevile karşı da oldukça sert eleştiriler yapmıştır. Temelde Maturidi geleneğine mensup bir alimin kelama ve tevile bu derece aşırı reaksiyon göstermesi onun ancak yenilikçi-selefi özelliği ile açılanabilir. Onun Maturidi olması bu durumu değiştirmemektedir. Zira eserlerinde Ebu Mansur Maturidi'nin de kendisi gibi tevilden uzak duruduğunu ispatlamaya çalışmaktadır ki, gerçekte Maturidi tevil karşıtı olması bir tarafa o, tevil yapılmasııı teşvik etmiş hatta bu konuyla ilgili bir de "Tevilatu'l-Kuran" adlı bir eser kaleme almıştır.

Damolla Sabit buna rağmen özellikle bazı yönleriyle kelamcı karaktere sahiptir. Bunlardan bir tanesi ahad haberlerle ilgili yaklaşımıdır; o ahad olarak gelen örneğin Miraç gibi haberlere inanmayanların Kuran'da yer almadığı için tartışmalı olduğunu vurgulamakta, akla ve tevile karşı olmasına rağmen aklı övücü şiirler yazmaktadır. Bu da onun mütekellim yönüyle bağlantılı olarak değerlendirilmelidir. 


\section{KAYNAKLAR}

Abdulbaki, Sabit Damolla, el-Kasidetu's-Seniyye fi'l-akidetu's-Sünniyye, Delhi, Şahicihan, mahbubi'l-matabi, 1932 , Akaid Cevheri, Delhi, Şahicihan, mahbubi'l-matabi. 1932. , Beyanu's-Sünne, Delhi, Şahicihan, mahbubi'l-matabi , 1932

Ayohanov, Zakir, "Dinî ve İçtimaî Meseleler İsimli Kitabının İntikâd ve Takriz", Şûra 1915/5

Bayrakdar, Mehmet, İslâm Felsefesine Giriş, Ankara 1997.

Bubi, Abdullah b. Abdülallam, Terakki-i Fünûn ve Maarif Dinsizliği Mucip mi? İ. N. Hari-tonov mat., Kazan 1902

Carullah, Musa, Edebiyat-ı Arabiye, Kazan, trhs. Mülahaza, Petersburg 1914

Çubukçu, İbrahim Agâh, Gazalî ve Şüphecilik, Ankara 1989

Gıfârî, Meyan Abdülevvel, “Akıl ile Nakil Meselesi”, Şûra, 1913/8.

İbn Rüşd, Faslu'l-Makal, çev. Süleyman Uludağ, İst. 1985

Maraş, İbrahim, Türk Dünyasında Dini Yenileşme, Ötüken yay. İstanbul 2002

Kurban,"Nur Ahmet, "Davet Adamlığından Devlet Adamlığına Sabit Damolla" Turkish Studies - International Periodical For The Languages, Literature and History of Turkish or Turkic, Volume 9/1 Winter 2014, Ankara.

Mercânî, Şehâbeddin, Kitâbu Nâzûrati'l Hakk fi Farziyyeti’l 'İşâi ve in Yegibi’ş Şafak, Hazane mat., Kazan 1287/1870

Ruzibaki, Mehmet, “19. Yüzyıl Orta Asya Dini Düşüncesi ve Kelamda Yenilik Hareketleri”, Doktora Tezi, Çanakkale Onsekiz Mart Üniversitesi Sosyal Bilimler Enstitüsü, Çanakkale 2014.

Suyargulov Rifat, "İdil-Ural Bölgesi Düşünürlerinden Ziyâeddin Kemâlî ve Kelami Görüş-leri” Ankara Üniversitesi Sosyal Bilimler Enstitüsü, Yüksek Lisans Tezi, Ankara 2012.

Yazoğlu, Ruhattin, "Gazâlî Düşüncesinde Ruh ve Ölüm”, Atatürk Üniversitesi Sosyal Bilimler Enstitüsü, Basılmamış Doktora Tezi, Erzurum 1998.

\section{On-Line Kaynaklar}

http://www.hurgokbayrak.com/yeni_sayfa_177.htm. Erişim tarihi 11. 06.2014. 